\title{
THE EFFECT OF LEARNING MOTIVATION, SELF-CONTROL AND CRITICAL THINKING ON STUDENTS' LEARNING ACHIEVEMENT AT OFFICE ADMINISTRATION EDUCATION STUDY PROGRAM, UNIVERSITAS NEGERI SURABAYA
}

\author{
Siti Aliva Mustikarini ${ }^{1}$, Durinda Puspasari ${ }^{2}$ \\ 1,2 Universitas Negeri Surabaya, Surabaya, Indonesia \\ ${ }^{1}$ siti.17080314023@mhs.unesa.ac.id, ${ }^{2}$ durindapuspasari@unesa.ac.id
}

\begin{abstract}
This study aimed to analyze the effect of learning motivation, self-control, and critical thinking on students' learning achievement at Office Administration Education study program, Universitas Negeri Surabaya. This study was quantitative research. The data were collected through questionnaires and interviews. The population in this study were students of the Office Administration Education study program, Universitas Negeri Surabaya, class of 2017, as many as 93 students. The samples in this study were selected through a total sample type, in which the number of samples were the same as the population, namely 93 students. Testing instruments in this study consisted of validity testing and reliability testing. The data analysis techniques used in this study were: 1) Classical assumptions consisting of normality test, multicollinearity test, and heteroscedasticity test; and 2) hypothesis testing using multiple linear regression. The results showed that: 1) there was a significant effect of learning motivation on the students' learning achievement at Office Administration Education study program, Universitas Negeri Surabaya;2) there was a significant effect of self-control on the students' learning achievement at Office Administration Education study program, Universitas Negeri Surabaya; 3) there was a significant effect of critical thinking on the students' learning achievement at Office Administration Education study program, Universitas Negeri Surabaya; and 4) there was a significant effect of learning motivation, self-control and critical thinking on the students' learning achievement at Office Administration Education study program, Universitas Negeri Surabaya.
\end{abstract}

Keywords: learning motivation, self-control, critical thinking, learning achievement

\section{PENGARUH MOTIVASI BELAJAR, SELF-CONTROL, DAN CRITICAL THINKING TERHADAP PRESTASI BELAJAR MAHASISWA PROGRAM STUDI PENDIDIKAN ADMINISTRASI PERKANTORAN UNIVERSITAS NEGERI SURABAYA}

\begin{abstract}
ABSTRAK
Penelitian ini bertujuan untuk menganalisis pengaruh motivasi belajar, self-control, dan critical thinking terhadap prestasi belajar mahasiswa program studi Pendidikan Administrasi Perkantoran Universitas Negeri Surabaya. Penelitian ini merupakan penelitian kuantitatif. Teknik pengumpulan data yang digunakan adalah angket dan wawancara. Populasi dalam penelitian ini adalah mahasiswa program studi Pendidikan Administrasi Perkantoran Universitas Negeri Surabaya angkatan 2017 sebanyak 93 mahasiswa. Sampel dalam penelitian ini menggunakan jenis sampel total, dengan jumlah sampel yang digunakan sama dengan jumlah populasi yaitu 93 mahasiswa. Uji coba instrumen dalam penelitian ini terdiri dari uji validitas dan uji reliabilitas. Teknik analisis data yang digunakan dalam penelitian ini yaitu: 1) uji asumsi klasik yang terdiri dari uji normalitas, uji multikolinieritas, dan uji heteroskedastisitas; 2) uji hipotesis menggunakan regresi linier berganda. Hasil penelitian menunjukkan bahwa: 1) terdapat pengaruh signifikan motivasi belajar terhadap prestasi belajar mahasiswa program studi Pendidikan Administrasi Perkantoran Universitas Negeri Surabaya; 2) terdapat pengaruh signifikan self-control terhadap prestasi belajar mahasiswa program studi Pendidikan Administrasi Perkantoran Universitas Negeri Surabaya; 3) terdapat pengaruh signifikan critical thinking terhadap prestasi belajar mahasiswa program studi Pendidikan Administrasi Perkantoran Universitas Negeri Surabaya; 4) terdapat pengaruh signifikan motivasi belajar, self-control, dan critical thinking terhadap prestasi belajar mahasiswa program studi Pendidikan Administrasi Perkantoran Universitas Negeri Surabaya.
\end{abstract}

Kata Kunci: motivasi belajar; self-control; critical thinking; prestasi belajar

\begin{tabular}{|c|c|c|}
\hline Submitted & Accepted & Published \\
\hline 30 Mei 2021 & 09 Agustus 2021 & 14 September 2021 \\
\hline
\end{tabular}

\begin{tabular}{|l|l|l|l|}
\hline Citation & $:$ & $\begin{array}{l}\text { Mustikarini, S.A., \& Puspasari, D. (2021). The Effect of Learning Motivation, Self-Control, and Critical Thinking on } \\
\text { Students Learning Achievement at Office Administration Education Study Program, Universitas Negeri }\end{array}$ \\
& & $\begin{array}{l}\text { Surabaya. Jurnal PAJAR (Pendidikan dan Pengajaran), 5(5), 1222-1243. DOI : } \\
\text { http://dx.doi.org/10.33578/pjr.v5i5.8428. }\end{array}$ \\
\hline
\end{tabular}




\section{PENDAHULUAN}

Pendidikan secara nasional di Indonesia didefinisikan sebagai usaha sadar seseorang dan terencana untuk mewujudkan suasana belajar dan proses pembelajaran agar peserta didik dapat secara aktif mengembangkan potensi dalam dirinya untuk memiliki kekuatan spiritual keagamaan, pengendalian diri, kepribadian, kecerdasan, akhlak mulia serta keterampilan yang diperlukan oleh dirinya, masyarakat atau lingkungan, bangsa dan Negara (Undang-Undang Republik Indonesia Nomor 20 tahun 2003). Belajar dan pembelajaran merupakan unsur utama dalam proses pendidikan. Belajar adalah proses interaksi terhadap lingkungan yang ada di sekitarnya. Belajar dapat dipandang sebagai proses yang mengarah pada tujuan dan proses berbuat melalui pengalaman seseorang (Rusman, 2017). Adapun pembelajaran merupakan proses interaksi antara peserta didik dengan pendidik, dengan bahan pembelajaran, metode, strategi dan sumber belajar di dalam suatu lingkungan belajar (Pane \& Dasopang, 2017). Proses pendidikan akan berjalan sesuai tujuan dengan adanya partisipasi aktif dari peserta didik. Dalam lingkup Perguruan Tinggi tentunya mahasiswa memiliki pengaruh yang besar dalam mencapai tujuan pembelajaran. Mahasiswa merupakan insan akademis yang dapat membawa pengaruh positif di lingkungan masyarakat, karena mahasiswa bagian dari generasi muda yang mampu memberikan perubahan ke arah yang lebih baik (agent of change).

Universitas Negeri Surabaya (UNESA) merupakan salah satu Perguruan Tinggi Negeri di Jawa Timur tepatnya di kota Surabaya yang memiliki dua lokasi kampus berbeda yaitu kampus Ketintang dan kampus Lidah Wetan dengan terakreditasi A. UNESA memiliki sebanyak 7 fakultas salah satunya adalah Fakultas Ekonomi dan Bisnis. Fakultas Ekonomi dan Bisnis memiliki 4 jurusan, salah satunya Jurusan Pendidikan Ekonomi, di dalam jurusan tersebut terdapat Program Studi Pendidikan Administrasi Perkantoran. Penelitian ini akan mengarah kepada tingkat pencapaian prestasi belajar mahasiswa selama menjadi mahasiswa aktif di lingkungan kampus.

Upaya dalam mencapai tujuan dan keberhasilan pembelajaran dapat diukur dengan prestasi belajar mahasiswa. Berdasarkan prestasi belajar maka dapat diketahui seberapa jauh mahasiswa menguasai materi dan keterampilan yang telah diajarkan. Hal ini sesuai dengan pendapat Syafi'i, Marfiyanto, \& Rodiyah (2018) yang menyatakan bahwa prestasi belajar merupakan serangkaian kegiatan pembelajaran yang telah dilakukan oleh seseorang dari suatu hasil yang telah dicapai sebagai wujud dari perubahan tingkah laku berdasarkan pengalaman dan wawasan dalam berinteraksi dengan lingkungannya. Mediawati (2010) menyatakan bahwa prestasi belajar merupakan cermin dari adanya keberhasilan kegiatan belajar mengajar peserta didik. Keberhasilan belajar mengajar di sekolah dapat dilihat berdasarkan perubahan pola tingkah laku peserta didik atau perilaku dari setiap individu yang diwujudkan dalam sikap pengetahuan dan keterampilan yang sesuai dengan tujuan tercapainya prestasi belajar peserta didik. Sunarsi (2017) juga menyatakan bahwa prestasi belajar merupakan suatu kecakapan nyata yang dimiliki seseorang yang dapat diukur dengan pengetahuan, sikap dan keterampilan sebagai interaksi aktif antara subyek dan obyek belajar selama proses pembelajaran berlangsung untuk tercapainya hasil belajar.

Penelitian Hamdu \& Agustina (2011) menyebutkan bahwa salah satu faktor yang mempengaruhi prestasi belajar adalah motivasi belajar. Adanya motivasi belajar maka siswa akan belajar lebih rajin, tekun, ulet dan memiliki konsentrasi penuh dalam proses pembelajaran. Motivasi belajar adalah suatu usaha yang disadari oleh seseorang untuk menggerakkan, mengarahkan dan menjaga tingkah laku agar terdorong untuk melakukan sesuatu sehingga dapat mencapai hasil dan tujuannya. Penelitian Khairiyah (2018) menyatakan bahwa adanya motivasi belajar sangat penting karena tanpa adanya dorongan dari lingkungan maka minat 
belajar akan menurun, namun dengan adanya dorongan atau motivasi akan membuat minat belajar seseorang akan meningkat. Menurut Suprihatin (2015), motivasi belajar diartikan sebagai kekuatan yang dimiliki oleh seseorang dalam melaksanakan suatu kegiatan. Emda (2017) menyatakan bahwa motivasi belajar adalah serangkaian usaha dalam melihat kondisi atau keadaan tertentu, dalam hal ini seseorang dapat melakukan sesuatu berdasarkan kemauan yang timbul dari diri siswa.

Perilaku mahasiswa dalam menyesuaikan diri maupun bergaul di lingkungan kampus sangatlah dibutuhkan. Perilaku harus sesuai dengan norma yang berlaku. Hal tersebut dapat berjalan sesuai norma apabila mahasiswa memiliki kontrol diri (self-control) dalam kehidupannya. Self-control dibutuhkan mahasiswa untuk mengatur dirinya sendiri guna memudahkan mereka dalam mencapai tujuan prestasi belajar yang diinginkan. Self-control merupakan fitur inti individu yang mengarah pada kesuksesan dan kebahagiaan dalam hidup (Muammar, 2015). Menurut Sriyanti (2012), self-control penting dimiliki oleh setiap orang untuk menghindari halhal negatif seperti membolos, menyontek, melanggar tata tertib, dan tidak mengerjakan tugas, karena rendahnya kontrol diri atau selfcontrol seseorang dapat berdampak negatif terhadap kehidupannya. Pembentukan self-control diawali sejak kecil, dalam hal ini orang tua menjadi pembentuk pertama. Suherman (2016) menjelaskan bahwa self-control dibutuhkan agar seseorang dapat membimbing, mengarahkan dan mengatur perilakunya yang pada akhirnya mengarah kepada konsekuensi positif yang diinginkan. Self-control memberikan sebuah keputusan melalui pertimbangan sadar untuk mengintegrasikan tindakan yang akan dilakukan untuk mencapai hasil atau tujuan yang diinginkan. Hamonangan \& Widyarto (2019) berpendapat bahwa self-control merupakan suatu kecakapan atau kemampuan yang dimiliki oleh setiap individu dalam kepekaan membaca situasi diri dan lingkungannya serta kemampuan dalam mengontrol dan mengelola faktor-faktor perilaku sesuai dengan situasi kondisi untuk berinteraksi atau bersosialisasi di lingkungan.
Selain self-control untuk meningkatkan prestasi belajar mahasiswa juga harus memiliki kemampuan berpikir kritis. Berpikir kritis merupakan berpikir tingkat tinggi dalam menyampaikan suatu gagasan yang dianggap benar atau sebaliknya berdasarkan pemikiran dan alas an yang rasional serta dapat dipertanggungjawabkan (Leonard \& Amanah, 2014). Kemampuan berpikir kritis seorang mahasiswa akan muncul dengan sendirinya atau bahkan dengan bantuan stimulus yang diberikan oleh dosen. Seorang pendidik atau dosen sangat dibutuhkan dalam memberikan motivasi kepada mahasiswa untuk mencoba belajar berpikir kritis. Menurut Nurfitriyanti, Rosa, \& Nursa'adah (2020), melatih siswa dalam berpikir kritis dimulai dari melibatkan kegiatan melihat, menganalisis, menyintesa dan menilai atau mengevaluasi setiap pengalaman atau kejadian yang telah dialami. Seseorang yang memiliki kemampuan berpikir kritis akan lebih mudah dalam mengatasi masalah berdasarkan fakta yang ada. Gotoh (2016) berpendapat bahwa critical thinking merupakan seperangkat keterampilan dan kecenderungan yang memungkinkan seseorang untuk memecahkan masalahnya secara logis dan mandiri serta kemampuan seseorang dalam mengambil keputusan. Tidak semua mahasiswa memiliki kemamuan berpikir kritis (critical thinking), namun di dalam proses pembelajaran tentu hal ini dibutuhkan oleh setiap mahasiswa. Zubaidah (2010) berpendapat bahwa berpikir kritis atau critical thinking merupakan proses dan kemampuan berpikir tingkat tinggi yang digunakan untuk menerapkan, memahami konsep dan mengevaluasi informasi yang diperoleh.

Berdasarkan studi pendahuluan yang dilakukan peneliti melalui wawancara dengan beberapa mahasiswa program studi Pendidikan Administrasi Perkantoran Universitas Negeri Surabaya menyatakan bahwa mahasiswa cenderung pasif dalam proses pembelajaran dan kurangnya pemahaman terhadap materi yang diajarkan. Hal tersebut dapat dilihat dari kurangnya rasa percaya diri dalam menyampaikan pendapat, kurangnya mahasiswa yang mau bertanya kepada dosen apabila terdapat materi yang belum dipahami, dan kurangnya motivasi 
belajar dari dalam diri mahasiswa yang dapat dilihat dari mahasiswa yang cenderung tidak memperhatikan pada saat pembelajaran berlangsung.

Tujuan penelitian ini adalah untuk menganalisis: 1) pengaruh motivasi belajar terhadap prestasi belajar mahasiswa program studi Pendidikan Administrasi Perkantoran Universitas Negeri Surabaya; 2) pengaruh self-control terhadap prestasi belajar mahasiswa program studi Pendidikan Administrasi Perkantoran Universitas Negeri Surabaya; 3) pengaruh critical thinking terhadap prestasi belajar mahasiswa program studi Pendidikan Administrasi Perkantoran Universitas Negeri Surabaya; 4) pengaruh motivasi belajar, self-control, dan critical thinking terhadap prestasi belajar mahasiswa program studi Pendidikan Administrasi Perkantoran Universitas Negeri Surabaya.

\section{KAJIAN TEORETIS Belajar}

Sejak dilahirkan, manusia telah banyak mengalami proses pembelajaran selama hidupnya. Artinya, aktivitas belajar telah akrab dengan kehidupan manusia. Berbagai aktivitas dilakukan dan diarahkan untuk mencapai tujuan pembelajaran. Belajar selalu melibatkan 3 hal pokok yaitu, adanya perubahan tingkah laku, sifat perubahan relatif permanen dan perubahan yang bersifat aktif. Dari ketiga hal pokok tersebut maka seseorang akan mencari informasi untuk mendapatkan suatu pengalaman dan pengetahuan dalam proses pembelajarannya (Emda, 2017). Tujuan dari adanya belajar dapat dilihat dari segi siswa dan guru. Belajar dari segi siswa yaitu sebagai proses. Dalam belajar siswa mengalami proses mental untuk menghadapi bahan belajar. Bahan belajar tersebut berupa keadaan alam, hewan, tumbuh-tumbuhan, manusia dan bahan yang terhimpun dalam buku pelajaran. Sedangkan dari segi guru, proses belajar tersebut tampak sebagai perilaku belajar tentang suatu hal. Proses belajar tersebut dapat diamati secara tidak langsung. Artinya, proses belajar yang merupakan proses internal siswa tidak dapat diamati, tetapi dapat dipahami oleh guru (Dimyati \& Mudjiono, 2013). Belajar merupakan suatu proses perubahan tingkah laku sebagai hasil interaksi individu dengan lingkungannya. Perubahan perilaku terhadap hasil belajar bersifat fungsional, aktif dan terarah. Proses perubahan tingkah laku dapat terjadi dalam keadaan ataupun kondisi yang berbeda-beda. Proses perubahan tingkah laku tersebut berupa interaksi antara peserta didik dengan pendidik, dengan bahan pembelajaran, metode dan strategi pembelajaran (Pane \& Dasopang, 2017).

Berdasarkan beberapa pendapat di atas maka dapat ditarik kesimpulan bahwa belajar merupakan pola perubahan tingkah laku seseorang menjadi yang lebih baik untuk kehidupannya. Perubahan tersebut memiliki dampak positif dan akan membawa seseorang ke arah kesuksesan. Belajar juga merupakan usaha yang dilakukan seseorang secara sadar untuk merubah sikap dan tingkah lakunya dengan cara mencari suatu pengalaman dalam setiap kegiatan belajarnya. Bagi setiap orang kegiatan belajar akan dijadikan sebagai sebuah pengalaman dan pembelajaran dalam hidupnya, karena dengan belajar seseorang akan berproses dan melakukan berbagai hal agar dapat mencapai tujuannya.

\section{Pembelajaran}

Pembelajaran merupakan suatu proses interaksi yang terjadi antara pendidik dan peserta didik dengan bahan pelajaran, metode pembelajaran, strategi pembelajaran dan sumber belajar dalam suatu lingkungan belajar. Keberhasilan suatu pembelajaran dapat dilihat dari tingkat keberhasilan dalam mencapai tujuan pendidikan. Tercapainya tujuan pembelajaran, maka dapat dikatakan bahwa seorang pendidik berhasil dalam mengajar. Sehingga pembelajaran yang efektif ditentukan dengan adanya proses interaksi yang baik antar komponen (Pane \& Dasopang, 2017). Pembelajaran merupakan proses interaksi positif antara pendidik dan peserta didik demi mencapai sebuah tujuan pembelajaran. Keberhasilan pencapaian suatu tujuan pendidikan terletak pada keefektifan proses pembelajaran (Emda, 2017). Arfani (2016) menyebutkan bahwa fungsi pembelajaran ada 2 yaitu pembelajaran sebagai sistem dan pembelajaran sebagai proses. Pembelajaran sebagai sistem merupakan sejumlah 
komponen yang terstruktur seperti tujuan pembelajaran, materi pembelajaran, strategi dan metode pembelajaran, media pembelajaran, pengkondisian kelas, evaluasi pembelajaran dan tindak lanjut pembelajaran. Sedangkan pembelajaran sebagai proses merupakan serangkaian upaya atau kegiatan pendidik untuk membuat siswa belajar, meliputi persiapan yang berupa merencanakan program pengajaran tahunan dan penyiapan segala kelengkapan belajar mengajarnya, melaksanakan kegiatan pembelajaran dengan mengacu pada persiapan pembelajaran yang telah dibuat, menindaklanjuti kegiatan pembelajaran yang telah dikelola.

Berdasarkan pendapat diatas maka dapat ditarik kesimpulan bahwa pembelajaran merupakan suatu proses interaksi yang terjadi antara pendidik dan peserta didik demi tercapainya suatu tujuan pembelajaran. Keberhasilan suatu pembelajaran terlatak pada kefektifan pembelajaran. Interaksi pendidik dan peserta didik dengan materi, strategi dan metode pembelajaran akan efektif apabila suasana proses pembelajaran berjalan secara aktif. Pembelajaran juga diartikan sebagai usaha yang dilakukan pendidik untuk membantu peserta didik mencapai tujuannya dan belajar sesuai dengan kebutuhan dan minatnya.

\section{Prestasi Belajar}

Prestasi belajar merupakan cerminan dari belajar. Semakin baik usaha belajar seseorang, maka semakin baik prestasi belajar yang akan diperolehnya. Ada beberapa macam faktor yang mempengaruhi pencapaian prestasi belajar siswa, baik dari faktor internal maupun faktor eksternal (Inayah, Martono, \& Sawiji, 2013). Prestasi belajar tidak bisa dipisahkan dari aktivitas belajar karena belajar merupakan suatu proses dan prestasi merupakan hasil dari proses pembelajaran tersebut. Prestasi belajar merupakan hasil yang diperoleh seseorang dalam proses belajar yang sesuai dengan kemampuan, kecakapan dan kesanggupan yang dimiliki. Prestasi belajar juga merupakan kecakapan nyata dari adanya usaha belajar yang dicapai baik berupa pengetahuan sikap atau keterampilan yang dimanifestasikan dalam bentuk nilai (Pratiwi, 2015). Prestasi akademik merupakan ukuran pengetahuan yang diperoleh dari pendidikan formal yang ditunjukkan dengan nilai ujian, nilai rata-rata dan derajat (Lawrence \& Vimala, 2012). Berdasarkan Buku Pedoman Akademik Universitas Negeri Surabaya (2019), prestasi belajar mahasiswa dapat diwujudkan dalam bentuk Indeks Prestasi (IP). Ada dua macam IP hasil belajar mahasiswa, yaitu IP setiap semester (IPS) dan IP komulatif (IPK). IPS adalah IP yang dihitung dari hasil belajar yang dicapai mahasiswa selama satu semester. Sedangkan IPK adalah IP yang dihitung dari hasil belajar seluruh mata kuliah yang diprogram dalam semester yang telah diselesaikan. Penetapan IPS dan IPK berdasarkan semua nilai mata kuliah yang diprogram (wajib dan pilihan), termasuk mata kuliah yang memperoleh nilai 0 (nol) atau $\mathrm{E}$.

Berdasarkan pendapat di atas maka dapat ditarik kesimpulan bahwa prestasi belajar merupakan wujud dari hasil usaha dalam proses pembelajaran. Prestasi belajar juga merupakan suatu hasil yang dicapai oleh seseorang melalui kerja keras dan semangatnya dalam belajar. Seseorang memiliki cara belajar dan sifat yang berbeda-beda sesuai dengan latar belakang dan tentunya akan mengakibatkan prestasi belajar yang diperoleh mereka berbeda. Prestasi belajar dalam penelitian ini diambil dari Indeks Prestasi Komulatif (IPK) mahasiswa program studi Pendidikan Administrasi Perkantoran Universitas Negeri Surabaya angkatan 2017.

\section{Motivasi Belajar}

Motivasi merupakan dorongan paling dasar untuk menggerakkan seseorang untuk bergerak dan bertindak dalam mencapai tujuan yang diinginkan. Motivasi memiliki peran penting dalam kelangsungan belajar seseorang. Sedangkan motivasi belajar merupakan keseluruhan daya penggerak dari dalam diri seseorang yang dapat menimbulkan kegiatan belajar dan memberikan arah pada pembelajaran sehingga tujuan yang diinginkan dapat dicapai (Masni, 2015). Motivasi belajar memiliki peran penting dalam keberhasilan belajar siswa. Motivasi belajar merupakan usaha yang dapat menyebabkan seseorang memiliki inisiatif bergerak dalam melakukan sesuatu untuk mencapai tujuan yang diinginkan. Dalam proses pembelajaran, motivasi dapat dikatakan sebagai 
penggerak di dalam diri seseorang yang dapat menimbulkan, menjamin kelangsungan belajar dan memberikan arah yang baik untuk mencapai suatu tujuan pembelajaran (Supriyanto, 2018). Kondisi internal peserta didik yang mempengaruhi proses pembelajaran sangat penting diperhatikan oleh seorang pendidik salah satunya adalah motivasi belajar, dimana motivasi belajar berperan sebagai pendorong yang dapat mengarah kepada tercapainya tujuan yang diinginkan.

Sehingga dari beberapa pendapat di atas dapat ditarik kesimpulan bahwa motivasi belajar memiliki peran penting dalam keberhasilan seseorang. Motivasi belajar berasal dari dorongan atau kekuatan dari dalam diri seseorang yang dapat membangun suatu keinginan untuk bersikap lebih baik dan berusaha mencapai tujuannya dengan caranya sendiri. Motivasi yang muncul dari dalam diri seseorang akan lebih berpengaruh positif terhadap dirinya dan juga dapat mempermudah dalam mencapai tujuan yang diinginkan. Motivasi belajar ini dapat mendorong seseorang untuk melakukan sesuatu dalam kegiatan pembelajaran sehingga hasil yang didapat akan lebih maksimal bila ada motivasi yang tepat di lingkungan tempat belajarnya. Dalam penelitian ini terdapat 4 indikator motivasi belajar menurut Keller (1987), yaitu: 1) Attention atau Perhatian merupakan unsur utama dalam motivasi belajar. Tujuannya untuk mengurangi kebosanan dan ketidakpedulian siswa dalam proses pembelajaran dengan memberikan stimulus yang sesuai; 2) Relevance atau Keterkaitan merupakan apa yang dibutuhkan oleh siswa. Dalam hal pembelajaran yang dikaitkan dengan kebutuhan siswa baik pengalaman maupun peluang karir sekarang dan masa depan untuk siswa; 3) Convidence atau Keyakinan merupakan rasa percaya diri dalam diri siswa. Kepercayaan diri dapat mempengaruhi ketekunan dan pencapaian siswa. Siswa yang percaya diri cenderung termotivasi untuk sukses dan aktif dalam pembelajaran; 4) Satisfaction atau Kepuasan merupakan rasa bangga yang dimiliki oleh seseorang atas apa yang telah dicapai. Siswa merasa termotivasi apabila diberikan sebuah imbalan atau penghargaan untuk tugasnya.

\section{Self-Control}

Self-control merupakan kondisi mental seseorang yang dapat mempengaruhi pembentukan perilaku lain. Kemampuan self-control ini dapat mempengaruhi terbentuknya perilaku yang baik, positif dan produktif serta keharmonisan hubungan dengan orang lain. Self-control juga mempengaruhi kebiasaan belajar, kedisiplinan, perilaku yang sesuai dengan norma di lingkungan sekolah maupun masyarakat dan pembentukan kebiasaan hidup lain yang baik. Pentingnya seseorang memiliki kontrol diri yang baik yaitu untuk bersikap dan menempatkan diri sesuai dengan keberadaannya (Sriyanti, 2012). Suherman (2016) menjelaskan bahwa self-control merupakan hal yang dibutuhkan oleh setiap individu agar individu dapat membimbing, mengarahkan dan mengatur dirinya ke perilaku yang positif. Menurut Aviyah \& Farid (2014), kontrol diri atau selfcontrol diartikan sebagai aktivitas pengendalian tingkah laku. Kemampuan yang dimiliki seseorang untuk menyusun, membimbing, mengatur dan mengarahkan bentuk perilaku yang dapat membawa seseorang ke arah yang lebih baik dan positif. Putri, Daharnis, \& Zikra (2017) mengemukakan bahwa kontrol diri atau selfcontrol merupakan suatu cara yang dapat digunakan untuk meminimalisir perilaku negatif seseorang yang mungkin dilakukan. Salah satu perilaku negatif yang dilakukan oleh seseorang yang memiliki self-control rendah adalah membolos sekolah. Duckworth, et al (2019) mengartikan bahwa self-control sebagai pengaturan pikiran, perasaan dan tindakan yang dimulai dari kebiasaan, aturan dan rencana yang secara sadar dilakukan oleh diri sendiri. Selfcontrol berasal dari dalam diri seseorang lebih penting dan self-control dapat dilatih sesuai dengan pilihan atau tingkah laku yang dilakukan.

Sehingga dari beberapa pendapat di atas dapat ditarik kesimpulan bahwa self-control merupakan cara seseorang dalam mengolah atau mengatur tingkah lakunya sehingga tidak akan melanggar norma-norma yang berlaku. Selfcontrol memiliki manfaat yang positif yaitu dapat mencegah, mengatur, dan mengelola dorongan dalam diri agar tidak melanggar standar moral yang berlaku untuk mendapatkan manfaat yang 
lebih besar. Self-control digunakan sebagai pengendalian tingkah laku, pikiran yang dimulai dari kebiasaan ataupun aktivitas yang dilakukan. Seseorang yang memiliki self-control akan lebih mudah dalam mencapai prestasi akademiknya. Dalam penelitian ini terdapat 3 indikator selfcontrol menurut Averill (1973), sebagai berikut: 1) kontrol perilaku (behavioral control) yaitu ketersediaan tanggapan yang dapat secara langsung mempengaruhi atau memodifikasi karakteristik objektif dari peristiwa yang mengancam. Kontrol perilaku dibagi menjadi dua bagian yaitu mengontrol perilaku atau mengatur pelaksanaan (regulated administration) dan memodifikasi stimulus (stimulus modification); 2) kontrol kognitif (cognitive control) yaitu cara sebuah peristiwa diinterpretasikan, dinilai, atau digabungkan ke dalam "rencana" kognitif. Kontrol kognitif dibedakan menjadi dua jenis yaitu memperoleh informasi dan penilaian. Adanya informasi yang dimiliki oleh individu mengenai suatu keadaan yang tidak menyenangkan, individu dapat mengantisipasi keadaan tersebut dengan berbagai pertimbangan; dan 3) mengontrol keputusan (decisional control) merupakan kesempatan untuk memilih diantara berbagai tindakan berdasarkan pada sesuatu yang diyakini atau disetujuinya. Kontrol diri dalam menentukan pilihan akan berfungsi baik dengan adanya suatu kesempatan, kebebasan, atau kemungkinan pada diri individu untuk memilih berbagai kemungkinan tindakan.

\section{Critical Thinking}

Critical thinking atau berpikir kritis merupakan kemampuan yang dimiliki seseorang untuk menyaring dengan cerdas, cermat, dan bertanggung jawab akan segala macam informasi yang diterima. Seseorang dituntut untuk memiliki kemampuan berpikir kritis (critical thinking). Ciri seseorang yang mampu berpikir kritis (critical thinking) adalah selalu mempertanyakan suatu gagasan atau informasi untuk memperoleh kebenaran. Seseorang yang memiliki pemikiran kritis dapat melihat secara tajam segala informasi yang diterima melalui pemahaman secara menyeluruh, menganalisis secara teliti dan memberikan penilaian yang dapat dipertanggungjawabkan (Pujiono, 2012). Critical thinking diartikan sebagai penilaian yang bertujuan untuk mengatur diri sendiri yang dapat menghasilkan interpretasi, analisis, evaluasi, dan inferensi serta penjelasan terkait bukti, konseptual kritis yang menjadi dasar dari penilaian tersebut. Seseorang yang berpikir kritis (critical thinking) yaitu seseorang yang memiliki kebiasaan ingin tahu, berpengalaman luas, open minded, fleksibel, bijak dalam membuat penilaian, rajin dalam mencari informasi yang relevan dan fokus dalam penyelidikan (Facione, 1990). Kelly (2009) berpendapat bahwa critical thinking sangat penting ditanamkan kepada siswa, karena membekali siswa dengan kompetensi atau kemampuan berpikir kritis (critical thinking) digunakan untuk menghadapi lingkungan sekitar atau sosial. Hidayah, Salim, \& Susiani (2017) berpendapat bahwa critical thinking merupakan kemampuan yang dimiliki oleh seseorang dalam menganalisis suatu gagasan dengan berpikir secara logis, reflektif, sistematis dan produktif yang diaplikasikan ke dalam membuat suatu pertimbangan dan pengambilan keputusan.

Berdasarkan beberapa pendapat di atas maka dapat disimpulkan bahwa critical thinking merupakan kemampuan yang dimiliki oleh seseorang untuk mengembangkan pengetahuan, kemampuan yang dimiliki, mengevaluasi serta mengungkapkannya dengan fakta dari berbagai sumber yang relevan. Seseorang yang berpikir kritis (critical thinking) adalah seseorang yang memiliki tanggung jawab terhadap apa yang dilakukan, memiliki pengalaman yang luas dan dapat mengambil keputusan dengan tepat. Pengambilan keputusan dapat dilakukan dengan berbagai pertimbangan yang matang dan selalu mencari kebenaran terhadap segala informasi yang diterimanya. Dalam penelitian ini terdapat 6 indikator self-control menurut Facione (2020) sebagai berikut: 1) Interpretasi digunakan untuk memahami dan mengungkapkan arti atau makna dari berbagai macam pengalaman, situasi, peristiwa, penilaian, kepercayaan, aturan, prosedur, atau kriteria; 2) Analisis digunakan untuk mengidentifikasi atau menganalisis hubungan inferensial yang diinginkan dan aktual diantara pernyataan, konsep, deskripsi, atau bentuk 
representasi lain; 3) Inferensi digunakan untuk menarik kesimpulan yang masuk akal, untuk membentuk dugaan dan hipotesis; 4) Evaluasi digunakan untuk menilai kredibilitas pernyataan dan menilai kekuatan logis dari inferensial aktual atau yang diinginkan hubungan antara pernyataan, deskripsi; 5) Penjelasan digunakan untuk menyatakan dan membenarkan penalaran itu dalam kerangka pembuktian, konseptual, pertimbangan metodologis; 6) Pengaturaan diri secara sadar untuk memantau aktivitas kognitif seseorang, elemen yang digunakan di dalamnya kegiatan, dan hasil yang diperoleh, terutama dengan menerapkan keterampilan dalam analisis, dan evaluasi.

\section{METODE PENELITIAN}

Jenis penelitian ini adalah penelitian korelasional dengan menggunakan pendekatan kuantitatif. Penelitian ini menggunakan dua variabel yaitu vaiabel independen dan variabel dependen, dimana variabel independen atau bebas yaitu motivasi belajar $\left(\mathrm{X}_{1}\right)$, self-control $\left(\mathrm{X}_{2}\right)$ dan critical thinking $\left(\mathrm{X}_{3}\right)$ sedangkan variabel dependen atau terikat yaitu prestasi belajar mahasiswa (Y). Populasi yang digunakan yaitu mahasiswa program studi Pendidikan Administrasi Perkantoran Universitas Negeri Surabaya angkatan 2017 sebanyak 93 mahasiswa yang terbagi menjadi 2 kelas, yaitu kelas A sebanyak 44 mahasiswa dan kelas B sebanyak 49 mahasiswa. Teknik pengambilan sampel dalam penelitian ini menggunakan teknik sampling total. Teknik sampling total adalah teknik pengambilan sampel dimana seluruh anggota populasi dijadikan sampel semua sebagai subyek yang dipelajari atau sebagai responden pemberi informasi (Sugiyono, 2019). Dalam penelitian ini jumlah sampel yang digunakan sama dengan jumlah populasi yaitu 93 mahasiswa. Teknik pengumpulan data yang digunakan adalah angket dan wawancara untuk studi pendahuluan dengan menggunakan pedoman wawancara tidak terstruktur. Angket disusun berdasarkan variabel dan indikator penelitian dengan skala pengukuran instrumen menggunakan skala likert. Angket ini digunakan untuk mendapatkan data dari variabel motivasi belajar, self-control dan critical thinking. Sedangkan untuk variabel prestasi belajar diambil dari Indeks Prestasi Komulatif (IPK) mahasiswa. Model konseptual dalam penelitian ini dapat dilihat pada gambar 1 sebagai berikut:

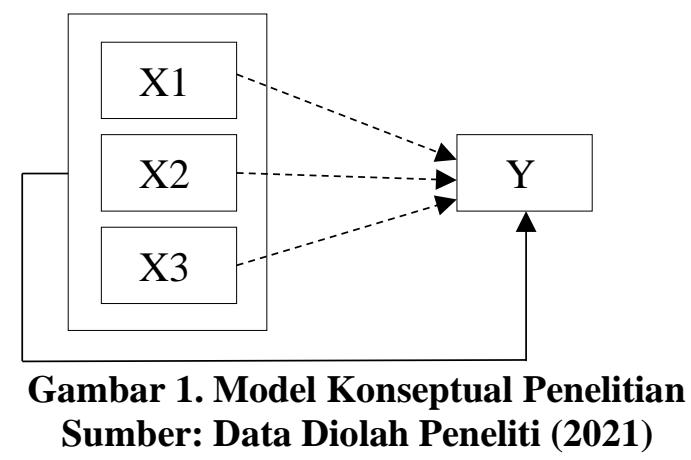

Keterangan :

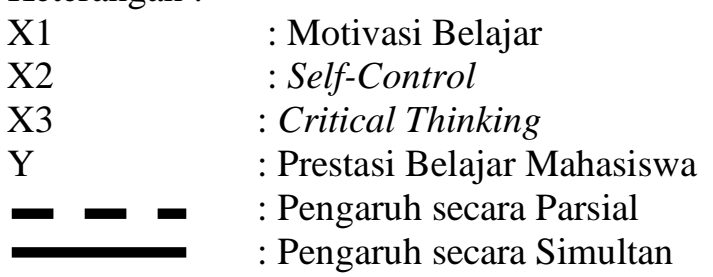

Uji coba instrumen dalam penelitian ini yaitu: 1) uji validitas, digunakan untuk mengukur kecukupan dan kelayakan interpretasi yang dibuat dari penilaian. Uji validitas ini juga untuk melihat apakah suatu alat ukur tersebut valid atau tidak dengan membandingkan nilai $r$ hitung $>r$ tabel; 2 ) uji reliabilitas, untuk mengetahui apakah alat ukur yang digunakan tepat untuk mengukur konsep yang hendak diukur dan menunjukkan pada sejauh 
mana hasil pengukuran relatif konsisten atau reliabel apabila pengukuran dilakukan berulang kali, data dapat dilihat pada Cronbach's Alpha > 0.6 maka data dikatakan reliabel atau konsisten (Sunarsi, 2017).

Teknik analisis data yang digunakan dalam penelitian ini yaitu: 1) Uji Asumsi Klasik yang terdiri dari a) Uji Normalitas Perngujian normalitas menggunakan One-Sample Kolmogorov-Smirnov Test dengan ketentuan nilai signifikansi > 0.05 maka dapat dikatakan data tersebut berdistribusi normal, b) Uji Multikolinieritas merupakan sebuah uji yang bertujuan untuk mengetahui ada atau tidak kemiripan yang dilakukan oleh satu variabel independen dengan variabel independen yang lain dalam satu model dengan ketentuan nilai tolerance $>0.1$ dan nilai VIF< 10 maka data dapat dinyatakan tidak mengalami multikolinieritas, c) Uji Heteroskedastisitas untuk mengetahui apakah terjadi heteroskedastisitas atau tidak dilihat dari gambar scatterplot, jika scatterplot nampak tidak ada pola yang jelas dan titik-titik menyebar di atas dan di bawah angka 0 pada sumbu $\mathrm{Y}$, maka dapat dinyatakan tidak terjadi heteroskedastisitas (Sunarsi, 2017); 2) Uji hipotesis menggunakan Regresi Linier Berganda yang bertujuan untuk menganalisis apakah terdapat pengaruh motivasi belajar $\left(\mathrm{X}_{1}\right)$, Self-Control $\left(\mathrm{X}_{2}\right)$, dan Critical Thinking $\left(\mathrm{X}_{3}\right)$ terhadap prestasi belajar mahasiswa program studi Pendidikan Administrasi Perkantoran Universitas Negeri Surabaya (Y) baik secara parsial maupun secara simultan.

\section{HASIL DAN PEMBAHASAN}

Hasil uji coba instrumen pada penelitian ini dapat ditunjukkan sebagai berikut:

1) Uji Validitas

Uji validitas dalam penelitian ini menggunakan program aplikasi SPSS 20 yang terdapat 69 item pernyataan telah diujikan dan diolah validitasnya. Hasil uji validitas menunjukkan bahwa 69 item pernyataan dinyatakan valid karena $r$ hitung $>r$ tabel. Variabel motivasi belajar $\left(\mathrm{X}_{1}\right)$ terdapat 11 pernyataan dinyatakan valid, variabel self-control $\left(\mathrm{X}_{2}\right)$ terdapat 23 pernyataan dinyatakan valid, dan variabel critical thinking $\left(\mathrm{X}_{3}\right)$ terdapat 29 pernyataan dinyatakan valid.

2) Uji Reliabilitas

Uji reliabilitas dalam penelitian ini menggunakan program aplikasi SPSS 20 yang dapat dilihat pada nilai Cronbach's Alpha motivasi belajar $0.808>0.6$; self-control $0.941>0.6$; dan critical thinking $0.961>0.6$ sehingga dinyatakan reliabel.

Hasil uji asumsi klasik pada penelitian ini dapat ditunjukkan sebagai berikut:

1) Uji Normalitas

Tabel 1. One-Sample Kolmogorov-

\begin{tabular}{|c|c|c|}
\hline \multicolumn{3}{|c|}{ Smirnov Test } \\
\hline & & $\begin{array}{l}\text { Unstandar } \\
\text { dized } \\
\text { Residual }\end{array}$ \\
\hline $\mathrm{N}$ & & 93 \\
\hline \multirow[b]{2}{*}{$\begin{array}{l}\text { Normal } \\
\text { Parameters }{ }^{\mathrm{a}, \mathrm{b}}\end{array}$} & Mean & $0 \mathrm{E}-7$ \\
\hline & $\begin{array}{l}\text { Std. } \\
\text { Deviation }\end{array}$ & .07881308 \\
\hline \multirow{3}{*}{$\begin{array}{l}\text { Most Extreme } \\
\text { Differences }\end{array}$} & Absolute & .122 \\
\hline & Positive & .122 \\
\hline & Negative & -.102 \\
\hline \multicolumn{2}{|c|}{ Kolmogorov-Smirnov Z } & 1.173 \\
\hline
\end{tabular}




\section{Asymp. Sig. (2-tailed) \\ a. Test distribution is Normal. \\ b. Calculated from data.}

Berdasarkan tabel 1 one-sample kolmogorov-smirnov test dapat dilihat bahwa nilai Asymp. Sig. (2-tailed) yaitu 0.127. Sehingga data dikatakan berdistribusi normal karena nilai signifikansi $>0.05$.

\section{2) Uji Multikolinieritas}

Hasil uji multikolinieritas didapatkan dengan nilai tolerance $>0.1$ dan VIF $<10$. Hasil analisis yang didapat nilai VIF untuk variabel motivasi belajar adalah $1.613<10$ dan nilai tolerance sebesar $0.620>0.1$; nilai VIF untuk variabel self-control adalah $1.484<10$ dan nilai tolerance sebesar $0.674>0.1$; nilai VIF untuk variabel critical thinking adalah $1.425<10$ dan nilai tolerance sebesar $0.702>0.1$. Sehingga dapat ditarik kesimpulan bahwa data tidak mengalami multikolinieritas.

Uji Heteroskedastisitas

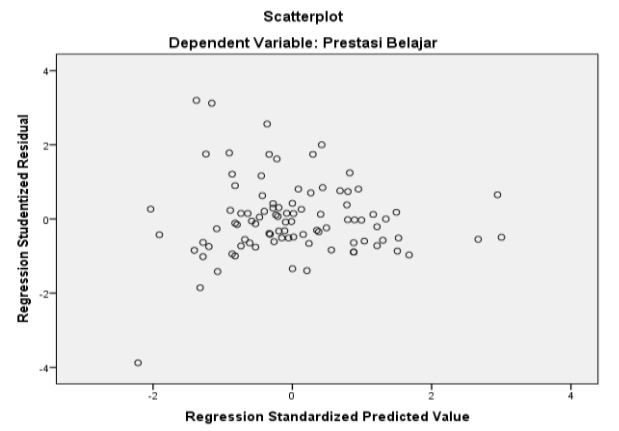

Gambar 2. Hasil Uji Heteroskedastisitas

Berdasarkan gambar 2 scatterplot di atas dapat diketahui bahwa titik-titik menyebar dan tidak membentuk pola di sekitar angka 0 pada sumbu Y, maka dapat dinyatakan tidak terjadi heteroskedastisitas.
Uji hipotesis pada penelitian ini menggunakan uji regresi linier berganda. Hasil uji regresi linier berganda dapat ditunjukkan sebagai berikut:

Tabel 2. Hasil Uji-t

\begin{tabular}{|c|c|c|c|c|c|c|c|c|}
\hline \multicolumn{9}{|c|}{ Coefficients ${ }^{\mathrm{a}}$} \\
\hline \multicolumn{2}{|c|}{ Model } & \multicolumn{2}{|c|}{$\begin{array}{l}\text { Unstandardized } \\
\text { Coefficients }\end{array}$} & \multirow{2}{*}{$\begin{array}{c}\text { Standardized } \\
\text { Coefficients }\end{array}$} & \multirow[t]{2}{*}{$\mathrm{t}$} & \multirow[t]{2}{*}{ Sig. } & \multicolumn{2}{|c|}{$\begin{array}{l}\text { Collinearity } \\
\text { Statistics }\end{array}$} \\
\hline & & $\mathrm{B}$ & Std. Error & & & & $\begin{array}{l}\text { Toler } \\
\text { ance }\end{array}$ & VIF \\
\hline \multirow{4}{*}{1} & (Constant) & .740 & .248 & & 2.986 & .004 & & \\
\hline & $\begin{array}{l}\text { Motivasi } \\
\text { Belajar }\end{array}$ & .022 & .004 & .401 & 5.009 & .000 & .620 & 1.613 \\
\hline & Self-Control & .013 & .004 & .287 & 3.738 & .000 & .674 & 1.484 \\
\hline & $\begin{array}{l}\text { Critical } \\
\text { Thinking }\end{array}$ & .007 & .002 & .295 & 3.921 & .000 & .702 & 1.425 \\
\hline
\end{tabular}




\section{Tabel 3. Hasil Uji-F}

\begin{tabular}{rlrrrrr}
\multicolumn{7}{c}{ ANOVA $^{\mathrm{a}}$} \\
\hline Model & $\begin{array}{l}\text { Sum of } \\
\text { Squares }\end{array}$ & df & $\begin{array}{c}\text { Mean } \\
\text { Square }\end{array}$ & F & Sig. \\
\hline \multirow{2}{*}{$\begin{array}{l}\text { Regres } \\
\text { sion }\end{array}$} & 1.048 & 3 & .349 & 54.427 & $.000^{\mathrm{b}}$ \\
1 & $\begin{array}{l}\text { Residu } \\
\text { al }\end{array}$ & .571 & 89 & .006 & & \\
& Total & 1.620 & 92 & & & \\
\hline
\end{tabular}

a. Dependent Variable: Prestasi Belajar

b. Predictors: (Constant), Motivasi Belajar, Self-Control, dan

Critical Thinking

Berdasarkan tabel 2 di atas dapat diketahui model persamaan regresi linier berganda sebagai berikut:

$\mathrm{Y}=0.740+0.022 \mathrm{X}_{1}+0.013 \mathrm{X}_{2}+0.007 \mathrm{X}_{3}$

Berdasarkan hasil persamaan regresi berganda tersebut, dapat dilihat bahwa koefisien regresi yang diperoleh bertanda positif, maka dapat dikatakan bahwa variabel motivasi belajar, selfcontrol dan critical thinking memiliki pengaruh yang positif terhadap prestasi belajar, dimana koefisien regresi motivasi belajar $\left(\mathrm{X}_{1}\right)$ sebesar 0.022 menyatakan bahwa setiap ada 1 peningkatan terhadap motivasi belajar $\left(\mathrm{X}_{1}\right)$ dalam diri mahasiswa akan meningkatkan prestasi belajar mahasiswa (Y) sebesar 0.022; koefisien regresi self-control $\left(\mathrm{X}_{2}\right)$ sebesar 0.013 menyatakan bahwa setiap ada 1 peningkatan terhadap self-control $\left(\mathrm{X}_{2}\right)$ dalam diri mahasiswa akan meningkatkkan prestasi belajar mahasiswa $(\mathrm{Y})$ sebesar 0.013; koefisien critical thinking $\left(\mathrm{X}_{3}\right)$ sebesar 0.007 menyatakan bahwa setiap ada 1 peningkatan terhadap critical thinking $\left(\mathrm{X}_{3}\right)$ dalam diri mahasiswa akan meningkatkan prestasi belajar mahasiswa (Y) sebesar 0.007.

\section{1) Uji-t}

Uji-t digunakan untuk mengetahui pengaruh variabel bebas terhadap variabel terikat secara parsial. Hasil uji-t dapat dilihat pada variabel motivasi belajar memperoleh nilai signifikansi $0.000<0.05$ dan $t_{\text {hitung }} 5.009>t_{\text {tabel }}$ 1.987. Artinya $\mathrm{H}_{1}$ yang menyatakan bahwa variabel motivasi belajar berpengaruh signifikan secara parsial terhadap prestasi belajar mahasiswa diterima. Variabel self-control memperoleh nilai signifikansi $0.000<0.05$ dan $\mathrm{t}_{\text {hitung }} 3.738>\mathrm{t}_{\text {tabel }}$ 1.987. Artinya $\mathrm{H}_{2}$ yang menyatakan bahwa variabel self-control berpengaruh signifikan secara parsial terhadap prestasi belajar mahasiswa diterima. Variabel critical thinking memperoleh nilai signifikansi $0.000<0.05$ dan thitung $3.921>$ $t_{\text {tabel }}$ 1.987. Artinya $\mathrm{H}_{3}$ yang menyatakan bahwa variabel critical thinking berpengaruh signifikan secara parsial terhadap prestasi belajar mahasiswa diterima.

\section{2) $\mathbf{U j i} \mathbf{i}-\mathbf{F}$}

Hasil uji-F dalam penelitian ini dapat dilihat pada variabel motivasi belajar, self-control, dan critical thinking memperoleh nilai signifikansi $0.000<0.05$ dan Fhitung $54.427>$ Ftabel 2.71. Artinya $\mathrm{H}_{4}$ yang menyatakan bahwa variabel motivasi belajar, self-control dan critical thinking berpengaruh signifikan secara simultan atau bersama-sama terhadap prestasi belajar mahasiswa diterima. Nilai koefisien determinasi pada kolom $R$ Square menunjukkan nilai sebesar 0.647 . Hal ini berarti variabel motivasi belajar, self-control, dan critical thinking memberikan pengaruh terhadap prestasi belajar mahasiswa sebesar $64,7 \%$. Sedangkan 35,3\% dipengaruhi variabel lain di luar penelitian ini.

Pengaruh Motivasi Belajar terhadap Prestasi Belajar Mahasiswa Program Studi Pendidikan Administrasi Perkantoran Universitas Negeri Surabaya

Berdasarkan hasil uji-t diketahui nilai sig. sebesar $0.000<0.05$ dan nilai $t_{\text {hitung }} 5.009>\mathrm{t}_{\text {tabel }}$ 1.987 yang menunjukkan bahwa $\mathrm{H}_{1}$ diterima, hal ini berarti terdapat pengaruh signifikan motivasi 
belajar terhadap prestasi belajar mahasiswa Program Studi Pendidikan Administrasi Perkantoran Universitas Negeri Surabaya. Penelitian ini sesuai dengan penelitian yang dilakukan oleh Kusuma, Adi, \& Sunarto (2018) yang menyatakan bahwa ada pengaruh positif dan signifikan antara motivasi belajar terhadap prestasi belajar, semakin tinggi motivasi belajar mahasiswa maka akan meningkat pula prestasi belajar mahasiswa, sebaliknya semakin rendah motivasi belajar mahasiswa maka akan semakin rendah pula prestasi belajar mahasiswa. Penelitian Pratama \& Arief (2019) mengungkapkan bahwa motivasi belajar berpengaruh terhadap prestasi belajar. Motivasi belajar yang tinggi akan memberikan dorongan positif dari siswa untuk belajar, hal tersebut akan terlihat dengan meningkatnya prestasi belajar siswa. Penelitian ini juga diperkuat oleh penelitian Kusuma \& Subkhan (2015) yang mengatakan bahwa ada pengaruh motivasi belajar terhadap prestasi belajar. Motivasi belajar memiliki pengaruh tinggi terhadap prestasi belajar siswa kelas XI IPS SMAN 3 Pati. Motivasi belajar dijadikan sebuah dorongan terhadap seseorang untuk belajar agar mendapatkan hasil yang baik. Penelitian Prasasty (2017) menyampaikan bahwa terdapat pengaruh yang signifikan antara motivasi belajar terhadap prestasi belajar matematika. Seseorang yang memiliki motivasi belajar yang tinggi akan lebih giat dalam belajar sehingga prestasi belajar akan meningkat. Penelitian Cleopatra (2015) menjelaskan bahwa ada pengaruh signifikan antara motivasi belajar terhadap prestasi belajar matematika siswa. Motivasi belajar memberikan peran yang sangat baik dalam meraih prestasi belajar siswa. Penelitian ini sejalan dengan penelitian Mulyaningsih (2014) yang mengatakan bahwa motivasi belajar siswa memiliki pengaruh positif dan signifikan terhadap prestasi belajar siswa SMK Negeri 5. Penelitian dari Cynthia, Martono, \& Indriayu (2015) menyatakan bahwa terdapat pengaruh yang signifikan antara motivasi belajar secara parsial terhadap prestasi belajar. Penelitian Sunadi (2013) mengungkapkan bahwa motivasi belajar berpengaruh signifikan secara parsial terhadap prestasi belajar siswa. Kegiatan belajar siswa sangat membutuhkan adanya motivasi belajar dalam mencapai prestasi yang baik. Penelitian Budiwibowo \& Nurhalim (2016) menyatakan bahwa ada pengaruh motivasi belajar terhadap prestasi belajar. Penelitian Ramdhan \& Harsono (2015) juga menyatakan bahwa terdapat pengaruh motivasi belajar terhadap prestasi belajar, hal ini dibuktikan dengan adanya peningkatan rata-rata IP mahasiswa dari semester satu hingga semester dua. Penelitian Chrisna \& Khairani (2019) menjelaskan bahwa motivasi belajar memiliki pengaruh terhadap prestasi akademik. Motivasi belajar membuat siswa lebih aktif dalam proses pembelajaran dan mampu mencapai prestasi belajar yang diinginkan.

Motivasi belajar mahasiswa sudah sangat baik dan dapat memberikan pengaruh terhadap prestasi belajar mahasiswa program studi Pendidikan Administrasi Perkantoran angkatan 2017. Besarnya pengaruh motivasi belajar terhadap prestasi belajar mahasiswa sebesar $38,4 \%$. Hal ini dapat dilihat dari rasa percaya diri mahasiswa dalam mengerjakan tugas dengan baik, percaya diri dalam menjawab pertanyaan yang diberikan dosen dan dapat menyampaikan gagasan dengan baik, melakukan presentasi sesuai dengan konsep dan dilakukan dengan benar. Mahasiswa yang memiliki motivasi belajar yang tinggi dapat dilihat dari mahasiswa yang berusaha mengerjakan tugas secara mandiri, selalu mendengarkan dosen pada saat menyampaikan materi, memperoleh mata kuliah sesuai dengan kebutuhannya dan dapat memberikan manfaat untuk kebutuhan karir di masa yang akan datang.

Motivasi belajar merupakan salah satu faktor pendukung dalam keberhasilan prestasi belajar mahasiswa. Keberhasilan prestasi belajar mahasiswa dapat dilihat dari motivasi belajar yang dimiliki oleh setiap individu saat mengikuti proses pembelajaran. Mahasiswa yang memiliki motivasi belajar yang tinggi tentunya akan terdorong untuk mencari pengetahuan, terpenuhinya kebutuhan pengalaman mahasiswa yang digunakan untuk masa depan dan karirnya, tekun dan aktif dalam perkuliahan untuk mencapai prestasi belajar yang diinginkan. Namun sebaliknya, mahasiswa yang memiliki tingkat motivasi belajar rendah kurang terdorong untuk mencari pengetahuan, kurang tekun dan tidak aktif dalam perkuliahan serta merasa cepat puas dengan capaian prestasi yang 
diperoleh tanpa memiliki keinginan yang lebih dalam meningkatkan prestasinya. Sejalan dengan penelitian yang dilakukan Muhammad (2016) yang menyatakan bahwa motivasi merupakan faktor penting dalam menentukan prestasi belajar siswa seperti bekerja keras untuk belajar dan penuh inspiratif, kreatif serta terarah. Siswa yang memiliki motivasi belajar tinggi akan selalu berusaha untuk lebih baik dan selalu ingin dipandang sebagai siswa yang berhasil.

Pengaruh Self-Control terhadap Prestasi Belajar Mahasiswa Program Studi Pendidikan Administrasi Perkantoran Universitas Negeri Surabaya. Berdasarkan hasil uji-t diketahui nilai sig. sebesar $0.000<0.05$ dan nilai $t_{\text {hitung }} 3.738>$ $t_{\text {tabel }} 1.987$ yang menunjukkan bahwa $\mathrm{H}_{2}$ diterima, hal ini berarti terdapat pengaruh signifikan selfcontrol terhadap prestasi belajar mahasiswa Program Studi Pendidikan Administrasi Perkantoran Universitas Negeri Surabaya. Penelitian ini sesuai dengan penelitian yang dilakukan oleh Intani \& Ifdil (2018) yang menyatakan bahwa terdapat hubungan positif dan signifikan antara kontrol diri terhadap prestasi belajar siswa. Artinya, apabila kontrol diri seseorang tinggi, maka prestasi belajar yang dicapainya akan tinggi dan sebaliknya, apabila kontrol diri seseorang rendah, maka prestasi belajar yang dicapainya juga rendah. Penelitian Karim \& Ghavam (2011) menyatakan bahwa terdapat hubungan positif antara self-control terhadap prestasi atau akademik. Perlu adanya peningkatan metode pembelajaran dan aktivitas pembelajaran yang sesuai dengan karakteristik mahasiswa agar self-control dapat ditingkatkan dan mampu mencapai prestasi yang diinginkan. Penelitian ini diperkuat dengan hasil penelitian dari Rohmatun, Fathoni, \& Haryono (2018) yang menjelaskan bahwa variabel self-control memiliki pengaruh positif terhadap burnout mahasiswa. Mahasiswa yang memiliki self-control yang tinggi maka perilaku belajar dapat diatur dan akan meningkatkan produktifitas belajar mahasiswa. Penelitian dari Ahmad (2017) yang menyampaikan bahwa terdapat pengaruh signifikan antara selfcontrol terhadap prestasi belajar mahasiswa. Siswa memiliki self-control yang baik dalam proses pembelajaran. Siswa yang memiliki self-control yang rendah atas dirinya sendiri, maka dapat dinyatakan siswa tersebut tidak akan dapat mengolah dirinya sendiri, mulai dari mengolah kecerdasan, tingkah laku dan emosinya sehingga siswa tidak memiliki self-control atas apa yang dilakukannya. Semakin besar self-control yang dimiliki maka semakin rendah tingkat prokratinasi akademik mahasiswa. Hasil penelitian Rachmaniar (2020) juga menyatakan bahwa self-control berpengaruh positif secara signifikan terhadap kemampuan seseorang dalam pembuatan keputusan karier. Sehingga semakin meningkat self-control siswa maka akan meningkat pula kemampuan pembuatan keputusan karier siswa.

Self-control yang dimiliki mahasiswa program studi Pendidikan Administrasi Perkantoran angkatan 2017 sudah sangat baik dan memberikan pengaruh terhadap prestasi belajar mahasiwa. Besarnya pengaruh self-control terhadap prestasi belajar mahasiswa sebesar 45,5\%. Hal ini dapat dilihat dari mahasiswa mentaati peraturan yang ditentukan oleh kampus, berbicara dengan sopan terhadap dosen maupun orang yang lebih tua di kampus, mematuhi prosedur yang diberikan dosen di kelas. Mahasiswa juga menggunakan pakaian yang rapi dan sopan selama mengikuti perkuliahan, dapat mengontrol diri pada saat berbicara dengan teman di kelas, dalam mengambil keputusan selalu menghargai pendapat orang lain, serta berpikir terlebih dahulu sebelum mengambil keputusan. Setiap perubahan variabel self-control akan berpengaruh positif terhadap prestasi belajar. Artinya, semakin tinggi self-control mahasiswa maka akan semakin mudah dalam mencapai prestasi belajar yang diinginkan. Dimana selfcontrol dapat mempengaruhi kebiasaan belajar, kedisiplinan, mengontrol perilaku, mampu memperkirakan atau mengantisipasi suatu peristiwa, mengontrol stimulus dan mengambil keputusan dengan tepat. Sebagaimana yang diungkapkan oleh Baumeister \& Exline (2000) bahwa self-control merupakan kemampuan diri untuk mengubah keadaan dan tanggapannya sendiri yang merupakan kunci dari keberhasilan dan pengaturan perilaku bagi setiap orang. Selfcontrol menjadi sebuah kunci karakter moral dan 
kekuatan seseorang yang akan mengarahkan seseorang pada sebuah keberhasilan.

Self-control merupakan salah satu faktor penting dalam mencapai prestasi belajar mahasiswa. Pencapaian prestasi belajar mahasiswa dapat dilihat dari pola tingkah laku mahasiswa dalam menginterpretasikan keadaan yang dihadapi, mempertimbangkan dan memilih tindakan serta mampu meminimalkan sebuah akibat dari apa yang dilakukan. Sehingga semakin baik self-control mahasiswa maka dapat membantu mahasiswa dalam mencapai prestasi belajar yang maksimal. Penelitian Azizah \& Indrawati (2015) menyebutkan bahwa self-control merupakan hal terpenting yang harus dimiliki oleh setiap individu. Karena dengan memiliki self-control yang baik dapat menentukan tingkah laku yang tidak diinginkan dan memiliki moral yang baik sesuai dengan harapan lingkungan serta dapat mengontrol dirinya dengan baik.

Pengaruh Critical Thinking terhadap Prestasi Belajar Mahasiswa Program Studi Pendidikan Administrasi Perkantoran Universitas Negeri Surabaya. Berdasarkan hasil uji-t diketahui nilai sig. sebesar $0.000<0.05$ dan nilai thitung 3.921 $>\mathrm{t}_{\text {tabel }} 1.987$ yang menunjukkan bahwa $\mathrm{H}_{3}$ diterima, hal ini berarti terdapat pengaruh signifikan critical thinking terhadap prestasi belajar mahasiswa Program Studi Pendidikan Administrasi Perkantoran Universitas Negeri Surabaya. Penelitian ini sesuai dengan penelitian yang dilakukan oleh Malawi \& Tristiar (2013) yang menyatakan bahwa kemampuan berpikir kritis berpengaruh dan berkontribusi secara signifikan terhadap prestasi belajar IPS. Prestasi belajar ditentukan oleh faktor kemampuan berpikir kritis, dimana peneliti berasumsi bahwa dengan mengembangkan kemampuan berpikir kritis dalam belajar dapat mengoptimalkan kemampuan kognitif terutama kemampuan dalam mengaplikasikan, menganalisis dan mengevaluasi. Sehingga dengan mengembangkan kemampuan berpikir kritis maka akan mempengaruhi prestasi belajarnya. Gunawan, Surya, \& Tryanasari (2014) dalam penelitiannya mengungkapkan bahwa terdapat pengaruh signifikan antara kemampuan berpikir kritis terhadap prestasi belajar. Berpikir kritis diukur dengan mengukur kemampuan memfokuskan masalah, kemampuan mengingat, memperoleh informasi, menganalisis dan mengevaluasi. Penelitian ini diperkuat dengan adanya penelitian yang dilakukan oleh Sihaloho (2017) yang menunjukkan bahwa terdapat hubungan yang positif dan signifikan antara kemampuan berpikir kritis terhadap prestasi belajar siswa. Hasil penelitian dari Nurfitriyanti, Rosa, \& Nursa'adah (2020) menjelaskan bahwa terdapat pengaruh positif yang signifikan antara kemampuan berpikir kritis terhadap prestasi belajar. Dengan adanya proses berpikir, maka akan membuat seseorang memiliki pengetahuan yang luas. Penelitian Kamaei \& Weisani (2013) menyampaikan bahwa critical thinking berpengaruh positif dan signifikan terhadap prestasi akademik. Artinya, siswa yang memiliki critical thinking yang tinggi mampu menerima dan mengolah informasi serta pengorganisasian dengan cara yang tepat, memiliki daya nalar yang baik, rasa ingin tahu dan siswa mampu menyelesaikan setiap tugas dan tantangan dalam setiap kegiatan pembelajaran. Penelitian Ahmad (2017) menunjukkan bahwa critical thinking berpengaruh signifikan terhadap prestasi belajar. Dalam hal ini setiap perubahan variabel critical thinking berpengaruh positif terhadap prestasi belajar, dimana setiap kenaikan variabel critical thinking maka prestasi belajar mahasiswa juga akan mengalami kenaikan. Penelitian Facriani, Sari, \& Nasriadi (2020) menyatakan bahwa terdapat pengaruh positif yang cukup signifikan antara kemampuan berpikir kritis terhadap prestasi belajar siswa. Berpikir kritis disebut sebagai suatu potensi yang dimiliki oleh setiap orang dan dapat diukur, dilatih serta dikembangkan. Penelitian Maiyetri (2014) juga menunjukkan bahwa critical thinking berpengaruh positif dan signifikan terhadap prestasi belajar siswa. Dalam hal ini semakin baik ciritcal thinking yang dimiliki siswa maka akan semakin baik pula prestasi belajar yang akan diraih siswa.

Critical thinking yang dimiliki mahasiswa program studi Pendidikan Administrasi Perkantoran angkatan 2017 sudah baik dan memberikan pengaruh terhadap prestasi belajar. Besarnya pengaruh critical thinking terhadap prestasi belajar mahasiswa sebesar $49,3 \%$. Hal ini 
dapat dilihat dari mahasiswa menyampaikan pendapat pada saat diskusi kelompok dan berdiskusi secara aktif dalam tugas kelompok. Mahasiswa mengkaitkan konsep teori yang diperoleh dengan permasalahan yang ada pada studi kasus yang diberikan dosen, menyelesaikan studi kasus yang diberikan dosen dan mengacu pada sumber referensi yang relevan, serta mampu memilih alternatif jawaban yang tepat terhadap permasalahan studi kasus yang diberikan dosen. Hal ini sejalan dengan teori yang dijelaskan oleh Arofah \& Nawantara (2019) yang menyatakan bahwa critical thinking merupakan kegiatan yang dilakukan individu agar dapat mengambil keputusan secara cermat dan berhati-hati. Critical thinking menjadi hal yang penting dalam keberhasilan pembelajaran. Siswa dapat mengevaluasi dirinya secara kritis, mengajarkan berbagai strategi dan keterampilan yang tepat serta sesuai dengan permasalahan yang dihadapi. Pernyataan serupa juga dijelaskan oleh Zubaidah (2018) yang menyampaikan bahwa kelebihan dari adanya critical thinking dapat menjadi keterampilan fundamental dalam mencermati dan memecahkan masalah. Hal ini penting dimiliki oleh siswa dalam menemukan sumber masalah dan bagaimana mencari serta menemukan solusi yang tepat atas masalah yang dihadapi sehingga dapat meningkatkan prestasi belajar siswa.

Peningkatan prestasi belajar mahasiswa dapat dilakukan dengan cara meningkatkan critical thinking mahasiswa dalam hal memahami atau mengungkapkan pengalaman, menganalisis permasalahan yang ada, dapat memberikan solusi, mengatasi masalah, dan mempertimbangkan informasi yang relevan serta melakukan pengaturan diri dengan mempertanggungjawabkan hal-hal yang dilakukan. Semakin tinggi critical thinking mahasiswa maka akan semakin tinggi pula prestasi belajar yang diperoleh mahasiswa tersebut, begitu pula sebaliknya semakin rendah critical thinking mahasiswa maka prestasi belajar mahasiswa kurang memuaskan. Sehingga dengan memiliki critical thinking maka mahasiswa akan lebih mudah dalam membuat keputusan secara tepat dan mampu mempertimbangkan hal-hal yang akan terjadi. Hal tersebut sejalan dengan pendapat Hidayah, Salim, \& Susiani (2017) yang menyatakan bahwa critical thinking memiliki pengaruh terhadap keberhasilan hidup seseorang karena critical thinking berkaitan dengan apa yang akan dikerjakan. Adanya critical thinking seseorang mampu berpikir secara logis dan rasional dalam menerima informasi serta sistematis dalam memecahkan masalah. Seseorang yang memiliki critical thinking dapat memanfaatkan informasi dan selalu mencari informasi yang relevan sehingga dapat mengevaluasi lalu memodifikasi untuk menganalisis ide yang terbaik.

Pengaruh Motivasi Belajar, Self-Control, dan Critical Thinking terhadap Prestasi Belajar Mahasiswa Program Studi Pendidikan Administrasi Perkantoran Universitas Negeri Surabaya. Berdasarkan hasil uji-F diketahui nilai sig. sebesar $0.000<0.05$ dan $\mathrm{F}_{\text {hitung }} 54.427>\mathrm{F}_{\text {tabel }}$ 2.71yang menunjukkan bahwa $\mathrm{H}_{4}$ diterima, hal ini berarti terdapat pengaruh signifikan motivasi belajar, self-control, dan critical thinking secara simultan terhadap prestasi belajar mahasiswa Program Studi Pendidikan Administrasi Perkantoran Universitas Negeri Surabaya. Penelitian ini sesuai dengan penelitian yang dilakukan oleh Ahmad (2017) yang menyatakan bahwa motivasi belajar, self-control dan critical thinking berpengaruh signifikan terhadap prestasi belajar. Dalam hal ini setiap perubahan variabel motivasi belajar, self-control dan critical thinking berpengaruh positif terhadap prestasi belajar, dimana semakin tinggi motivasi belajar, selfcontrol dan critical thinking mahasiswa maka prestasi belajar mahasiswa juga tinggi. Hasil penelitian tersebut sejalan dengan penelitian yang dilakukan oleh Rosana (2014) yang mengatakan bahwa terdapat pengaruh signifikan antara penggunaan metode pembelajaran dan kemampuan berpikir kritis terhadap hasil belajar siswa. Penelitian Kamaei \& Weisani (2013) menjelaskan bahwa motivasi berprestasi, critical thinking, dan berpikir kreatif berpengaruh positif dan signifikan terhadap prestasi belajar. Dalam hal ini semakin tinggi prestasi belajar siswa maka akan semakin tinggi pula motivasi berprestasi, critical thinking, dan berpikir kreatif yang dimiliki oleh siswa. Penelitian Devi (2018) menyatakan bahwa terdapat pengaruh positif motivasi belajar dan pemanfaatan waktu belajar siswa di luar jam pelajaran secara 
bersama-sama terhadap prestasi belajar siswa. Penelitian Wicaksono (2014) menyampaikan bahwa keterampilan metakognitif dan critical thinking berpengaruh positif terhadap hasil belajar kognitif siswa. Hal ini menunjukkan bahwa hasil belajar kognitif dipengaruhi oleh keterampilan metakognitif dan critical thinking siswa. Artinya, semakin baik keterampilan metakognitif dan critical thinking siswa maka semakin baik hasil belajar kognitif yang dicapai siswa. Hasil penelitian Triastutik \& Sutoyo (2020) menunjukkan bahwa self-control berpengaruh positif dan signifikan terhadap perilaku disiplin tata tertib sekolah pada siswa SMA. Dimana jika siswa memiliki self-conrol yang baik maka siswa akan lebih menampakkan perilaku disiplin terhadap tata tertib sekolah. Hasil penelitian Sekaringtyas (2017) memperoleh hasil bahwa critical thinking berpengaruh signifikan dan positif terhadap hasil belajar IPA. Dalam hal ini semakin tinggi critical thinking siswa maka akan semakin tinggi pula hasil belajar yang diraih siswa atau dengan kata lain agar siswa dapat memperoleh hasil belajar yang maksimal maka harus memiliki critical thinking yang baik. Penelitian Kusumastuti, Rusilowati, \& Nugroho (2019) menyatakan bahwa keterampilan kemampuan berpikir kritis dan kemampuan literasi sains memiliki pengaruh positif dan signifikan. Dalam hal ini semakin tinggi keterampilan berpikir kritis maka semakin tinggi pula kemampuan literasi sains yang dimiliki. Penelitian Fitri \& Armida (2020) juga menyatakan bahwa motivasi belajar dan persepsi kemampuan berpikir kritis berpengaruh positif dan signifikan terhadap hasil belajar ekonomi siswa.

Nilai koefisien determinasi pada kolom $R$ Square menunjukkan nilai sebesar 0,647. Motivasi belajar, self-control, dan critical thinking berpengaruh terhadap prestasi belajar mahasiswa. Motivasi belajar, self-control, dan critical thinking memberikan pengaruh terhadap prestasi belajar mahasiswa sebesar $64,7 \%$. Sedangkan 35,3\% dipengaruhi variabel lain di luar penelitian ini. Dalam hal ini juga berarti bahwa semakin tinggi motivasi belajar, self-control, dan critical thinking maka tingkat prestasi belajar yang diperoleh mahasiswa juga tinggi. Prestasi belajar mahasiswa dikatakan baik dengan adanya dukungan dari motivasi belajar, self-control dan critical thinking yang dimiliki mahasiswa. Hal tersebut ditunjukkan dengan adanya mahasiswa yang aktif dalam pembelajaran, lugas dalam menyampaikan gagasan, berpakaian rapi dan sopan, saling menghargai pendapat, menyelesaikan tugas dengan baik dan menyelesaikan setiap permasalahan dengan pertimbangan yang matang. Disamping itu diperlukan adanya kompetensi yang dimiliki oleh pendidik melalui penyampaian materi pelajaran dengan baik diharapkan mampu membimbing peserta didik untuk belajar mandiri melalui berbagai sumber belajar yang diterapkan di dalam proses pembelajaran (Puspasari \& Puspasari, 2019).

\section{SIMPULAN DAN REKOMENDASI}

Berdasarkan hasil dan pembahasan, maka dapat disimpulkan bahwa terdapat pengaruh signifikan motivasi belajar, self-control, dan critical thinking terhadap prestasi belajar mahasiswa Program Studi Pendidikan Administrasi Perkantoran Universitas Negeri Surabaya baik secara parsial maupun simultan. Diartikan bahwa semakin baik motivasi belajar, self-control dan critical thinking mahasiswa maka akan semakin baik prestasi belajar yang akan diraih. Dengan diketahui besarnya pengaruh antara motivasi belajar, self-control dan critical thinking maka dapat di tentukan hal-hal yang dapat meningkatkan prestasi belajar mahasiswa dalam kegiatan belajar mengajar.

Mahasiswa yang memiliki motivasi belajar tinggi cenderung akan mudah dalam mengikuti pembelajaran karena memiliki rasa ingin tahu yang besar dan merasa termotivasi untuk terus belajar hal baru. Sedangkan mahasiswa yang memiliki self-control tinggi akan mempengaruhi pola tingkah lakunya, memiliki tanggung jawab terhadap apa yang dilakukan dan mampu mengontrol dirinya dengan baik. Dan mahasiswa yang memiliki critical thinking tinggi mampu mengolah informasi dengan baik, mampu mencari solusi atau pemecahan masalah yang baik serta dapat mengambil keputusan dengan tepat. Dengan demikian motivasi belajar, self-control dan critical thinking dalam proses belajar 
mahasiswa mampu memberikan pengaruh prestasi belajar mahasiswa semakin optimal.

Adapun saran yang dapat diberikan oleh peneliti, yaitu: 1) diharapkan pendidik selalu memberikan motivasi belajar agar dapat meningkatkan prestasi belajar mahasiswa; 2) diharapkan pendidik selalu memperhatikan selfcontrol agar mahasiswa dapat mengatur pola pikir dan pola tingkah laku dalam lingkungan belajar dan masyarakat; 3) diharapkan pendidik selalu memperhatikan critical thinking yang dimiliki mahasiswa agar dapat mengolah informasi dengan baik dan benar serta mencari sumber yang relevan; 4) menambah variabel lain pada penelitian selanjutnya dengan menggunakan sampel dan populasi lain selain mahasiswa Program Studi Pendidikan Administrasi Perkantoran Universitas Negeri Surabaya.

\section{DAFTAR PUSTAKA}

Ahmad, H. (2017). Pengaruh Motivasi Belajar, Self-Control dan Critical Thinking terhadap Prestasi Belajar Mahasiswa Prodi Pendidikan Ekonomi STKIP Situbondo. Jurnal Ekonomi Pendidikan dan Kewirausahaan, 5(2), 263-274. https://journal.unesa.ac.id/index.php/jepk/ article/view/1598/1076.

Arfani, L. (2016). Pengaruh Hakikat Pendidikan, Belajar dan Pembelajaran. Junal PPKn \& Hukum, 11(2), 81-97. https://pbpp.ejournal.unri.ac.id/index.php/ JPB/article/view/5160/4838.

Arofah, L. \& Nawantara, R. D. (2019). Pentingnya Critical Thinking bagi Siswa dalam Menghadapi Society 5.0. Prosiding Seminar Nasional Pendidikan dan Pembelajaran, hlm. 538-545, Universitas Nusantara PGRI Kediri. http://ojs.semdikjar.fkip.unpkediri.ac.id/in dex.php/SEMDIKJAR/article/view/61.

Averill, J. R. (1973). Personal Control Over Aversive Stimuli and Its Relationship to Stress. Psychological Bulletin, 80(4), 286$303 . \quad$ https://scihub.scihubtw.tw/10.1037/h0034845.

Aviyah, E. \& Farid, M. (2014). Religiusitas, Kontrol Diri dan Kenakalan Remaja.
Jurnal Psikologi Indonesia, 3(2), 126-129. http://jurnal.untag-

sby.ac.id/index.php/persona/article/view/3 76/334.

Azizah, F. N. \& Indrawati, E. S. (2015). Kontrol Diri dan Gaya Hidup Hedonis pada Mahasiswa Fakultas Ekonomi dan Bisnis Universitas Diponegoro. Jurnal Empati, 4(4), 156-162. https://ejournal3.undip.ac.id/index.php/em pati/article/view/14313.

Baumeister, R. F. \& Exline, J. L. (2000). SelfControl, Morality and Human Strength. Journal of Social and Clinical Psychology, 19(1), 29-42. https://scihub.scihubtw.tw/10.1521/jscp.2000.19.1. 29.

Budiwibowo, A. K. \& Nurhalim, K. (2016). Pengaruh Motivasi Belajar terhadap Prestasi Belajar Warga Belajar Kejar Paket C. Journal of Nonformal Education, 2(2), 169-174. https://journal.unnes.ac.id/nju/index.php/j ne/article/view/6789.

Buku Pedoman Akademik Universitas Negeri Surabaya. (2019). https://statik.unesa.ac.id/profileunesa_kon ten_statik/uploads/bakpk/file/ff3a061a23f2-43d7-8017-bdcccdb41b26.pdf.

Chrisna, H. \& Khairani. (2019). Pengaruh Perilaku Belajar, Pengendalian Diri, Motivasi, Empati, Keterampilan dan Kepercayaan Diri terhadap Prestasi Akademik Mahasiswa Prodi Akuntansi Universitas Pembangunan Panca Budi Medan. Jurnal Akuntansi Bisnis dan Publik, 10(2), 87100.

http://jurnal.pancabudi.ac.id/index.php/ak untansibisnisdanpublik/article/view/575.

Cleopatra, M. (2015). Pengaruh Gaya Hidup dan Motivasi Belajar terhadap Prestasi Belajar Matematika. Jurnal Ilmu Pendidikan MIPA, 5(2), 168-181. https://journal.lppmunindra.ac.id/index.ph $\mathrm{p} /$ Formatif/article/view/336.

Cynthia, L., Martono, T., \& Indriayu, M. (2015). Pengaruh Fasilitas Belajar dan Motivasi Belajar terhadap Prestasi Belajar Mata 
Pelajaran Ekonomi Siswa Kelas XI IIS di SMA Negeri 5 Surakarta Tahun Ajaran 2015/2016. Jurnal Pendidikan Bisnis dan Ekonomi, 1(2), 1-20. https://jurnal.uns.ac.id/bise/article/view/1 7966/14340.

Devi, A. P. C. (2018). Pengaruh Motivasi Belajar dan Pemanfaatan Waktu Belajar Siswa di Luar Jam Pembelajaran terhadap Prestasi Belajar Akuntansi. Jurnal Pendidikan Akuntansi Indonesia, 16(1), 23-34. https://journal.uny.ac.id/index.php/jpakun /article/view/20165.

Dimyati \& Mudjiono. (2013). Belajar dan Pembelajaran. Jakarta: Rineka Cipta.

Duckworth, A. L., et al. (2019). Self-Control and Academic Achievement. Annual Reviews of Psychology, 70(1), 373-390. https://scihub.scihubtw.tw/10.1146/annurev-psych010418-103230.

Emda, A. (2017). Kedudukan Motivasi Belajar Siswa dalam Pembelajaran. Lantanida Journal, 5(2), 93-196. https://jurnal.arraniry.ac.id/index.php/lantanida/article/vie w/2838/2064.

Facione, P. A. (1990). Critical Thinking: a Statement of Expert Consensus for Purpose of Educational Assessment and Instruction. The Complete American Philosophical Association Delphi Research Report, 1-19. https://www.qcc.cuny.edu/SocialSciences /ppecorino/CT-Expert-Report.pdf.

Facione, P. A. (2020). Critical Thinking: What It is and Why It Counts. Insight Assessment, 131 . https://www.insightassessment.com/wpcontent/uploads/ia/pdf/whatwhy.pdf.

Facriani, D., Sari, I. K., \& Nasriadi, A. (2020). Pengaruh Kemampuan Berpikir Kritis Matematis terhadap Prestasi Belajar Siswa SMA Negeri 3 Banda Aceh. Prosiding Seminar Nasional Pendidikan, hlm. 50-65, STKIP Bina Bangsa Getsempena, Banda Aceh. https://repository.bbg.ac.id/handle/917.

Fitri, S. D. \& Armida. (2020). Pengaruh Motivasi Belajar dan Persepsi Kemampuan Berpikir
Kritis terhadap Hasil Belajar Ekonomi Siswa. Jurnal Pendidikan Ekonomi, 3(3), 468-476.

http://ejournal.unp.ac.id/students/index.ph p/pek/article/view/9996.

Gotoh, Y. (2016). Development of Critical Thinking with Metacognitive Regulation. Prosiding International Conference on Cognition and Exploratory Learning in Digital Age, hlm. 353-356. Niigata University.

https://eric.ed.gov/?q=critical+thinking\&i $\mathrm{d}=$ ED571408.

Gunawan, I., Surya, S. N., \& Tryanasari, D. (2014). Hubungan Kemampuan Berpikir Kreatif dan Kritis dengan Prestasi Belajar Mahasiswa pada Matakuliah Konsep Sains II Prodi PGSD IKIP PGRI Madiun. Jurnal Pendidikan Dasar dan Pembelajaran, 4(1), 10-40. http://ejournal.unipma.ac.id/index.php/PE/article/ view/304.

Hamdu, G. \& Agustina, L. (2011). Pengaruh Motivasi Belajar Siswa terhadap Prestasi Belajar IPA di Sekolah Dasar. Jurnal Penelitian Pendidikan, 12(1), 81-86. https://d1wqtxts 1xzle7.cloudfront.net/359 68572/8-

Ghullam_Hamdu1.pdf?1418738267=\&res ponse-

contentdisposition=inline $\% 3 \mathrm{~B}+$ filename \%3DPENGARUH_MOTIVASI_BELAJ AR_SISWA_TERHADAP.pdf\&Expires= 1611463048\&Signature $=$ YnFURTkeSHji azgAgC4TDf-

ABhu2w 3SbNOE53Cg8kBRUaaud4O.

Hamonangan, R. H. \& Widyarto, S. (2019). Pengaruh Self Regulated Learning dan Self Control terhadap Hasil Belajar Bahasa Indonesia. Jurnal Dimensi Pendidikan dan Pembelajaran, $\quad 7(1), \quad 6-10$. http://journal.umpo.ac.id/index.php/dimen si/article/view/1056.

Hidayah, R., Salim, M., \& Susiani, T.S. (2017). Critical Thinking Skill: Konsep dan Indikator Penilaian. Jurnal Taman Cendekia, $\quad 1(2), \quad$ 127-133. 
https://core.ac.uk/download/pdf/23038396 5.pdf.

Inayah, R., Martono, T. \& Sawiji, H. (2013). Pengaruh Kompetensi Guru, Motivasi Belajar Siswa, dan Fasilitas Belajar terhadap Prestasi Belajar Mata Pelajaran Ekonomi pada Siswa Kelas XI IPS SMA Negeri 1 Lasem Jawa Tengah Tahun Pelajaran 2011/2012. Jurnal Pendidikan Insan Mandiri, 1(1), 2-13. https://core.ac.uk/download/pdf/12346718 .pdf.

Intani, C. P. \& Ifdil. (2018). Hubungan Kontrol Diri dengan Prestasi Belajar Siswa. Jurnal Pendidikan Indonesia, 4(2), 65-70. http://www.jurnal.iicet.org/index.php/jedu/article/view/191/268.

Kamaei, A. \& Weisani, M. (2013). The Relationship Between Achievement Motivation, Critical Thinking and Creative Thinking with Academic Performance. Indian Journal of Fundamental and Applied Life Sciences, 3(4), 121-127. https://www.cibtech.org/J-LIFE-

SCIENCES/PUBLICATIONS/2013/Vol_ 3_No_4/JLS-18-15-ATEFEH-THEPERFORMANCE.pdf.

Karim, S. \& Ghavam, E. (2011). The Relationship Between Self-Control, Self-Effectiveness, Academic Performance and Tendency towards Academic Cheating: a Case Report of a University Survey in Iran. Malaysian Journal of Distance Education, 13(2), 1-8. http://mjde.usm.my/vol13_2_2011/mjde1 3_2_1.pdf.

Keller, J. M. (1987). Development and Use of the ARCS Model of Instructional Design. Jurnal of Intructional Development, 10(3), 2-10. https://scihub.do/https://doi.org/10.1007/BF029057 80.

Kelly, Y. L. K. (2009). Assessing Students' Critical Thinking Performance: Urging for Measurements Using Multi-Response Format. Elsevier, 4(1), 71-76. https://scihub.scihubtw.tw/10.1016/j.tsc.2009.02.00 1.
Khairiyah, U. (2018). Pengaruh Minat dan Motivasi Belajar Mahasiswa terhadap Prestasi Mahasiswa PGMI UNISLA. Junal Pendidikan Guru Madrasah Ibtidaiyah, 2(1), 31-35. http://journalfai.unisla.ac.id/index.php/atthulab/article/view/197/184.

Kusuma, D., Adi, B. W., \& Sunarto. (2018). Pengaruh Minat Baca, Motivasi Belajar dan Lingkungan Teman Sebaya terhadap Prestasi Belajar Mahasiswa Pendidikan Ekonomi Tahun Angkatan 2014-2016. Jurnal Pendidikan Bisnis dan Ekonomi, 4(1), $1-15$. https://jurnal.fkip.uns.ac.id/index.php/ptn/ article/view/11973/8537.

Kusumastuti, R. P., Rusilowati, A., \& Nugroho, S. E. (2019). Pengaruh Keterampilan Berpikir Kritis terhadap Literasi Sains Siswa. UPEJ Unnes Physics Education Journal, 8(3), 255-261. https://journal.unnes.ac.id/sju/index.php/u pej/article/view/35624.

Kusuma, Z. L. \& Subkhan. (2015). Pengaruh Motivasi Belajar dan Kedisiplinan Belajar terhadap Prestasi Belajar Mata Pelajaran Akuntansi Siswa Kelas XI IPS SMAN 3 Pati Tahun Pelajaran 2013/2014. Economic Education Analysis Journal, 4(1), 164-171. https://journal.unnes.ac.id/sju/index.php/e eaj/article/view/4693/4329.

Lawrence, A. S. A. \& Vimala, A. (2012). School Environment and Academic Achievment of Standard IX Students. Journal of Educational and Instructional Studies in the World, 2(3), 210-215. https://files.eric.ed.gov/fulltext/ED542331 .pdf.

Leonard \& Amanah, N. (2014). Pengaruh Adversity Quotient (AQ) dan Kemampuan Berpikir Kritis terhadap Prestasi Belajar Matematika. Perspektif Ilmu Pendidikan, 28(1), 55-64. https://journal.lppmunindra.ac.id/index.ph p/repository/article/view/1049/977.

Maiyetri, R. (2014). Pengaruh Gaya Belajar Visual, Gaya Belajar Auditorial dan 
Kemampuan Berpikir Kritis terhadap Prestasi Belajar Siswa Kelas XII IPS pada Mata Pelajaran Ekonomi di SMA Negeri 8 Padang. Journal of Economic Education, 2(2), 100-109. http://ejournal.stkip-pgrisumbar.ac.id/index.php/economica/article/ view/260.

Malawi, I. \& Tristiar, A. (2013). Pengaruh Konsentrasi dan Kemampuan Berpikir Kritis terhadap Prestasi Belajar IPS Siswa Kelas V SDN Manisrejo 1 Kabupaten Magetan. Jurnal Pendidikan Dasar dan Pembelajaran, 3(2), 118-131. http://ejournal.unipma.ac.id/index.php/PE/article/ view/272/244.

Mediawati, E. (2010). Pengaruh Motivasi Belajar Mahasiswa dan Kompetensi Dosen terhadap Prestasi Belajar. Jurnal Pendidikan Ekonomi Dinamika Pendidikan, 5(2), 135-146. https://journal.unnes.ac.id/nju/index.php/ DP/article/view/4922/4070.

Muammar, O. M. (2015). Intelligence and SelfControl Predict Academic Performance of Gifted and Non-gifted Students. Turkish Journal of Giftedness and Education, 5(1), 67-81.

https://www.researchgate.net/publication/ 280621969_Intelligence_and_Self-

Control_Predict_Academic_Performance _of_Gifted_and_Non-gifted_Students.

Muhammad, M. (2016). Pengaruh Motivasi dalam Pembelajaran. Lantanida Journal, 4(2), 88-97. https://jurnal.arraniry.ac.id/index.php/lantanida/article/vie $\mathrm{w} / 1881 / 1402$.

Mulyaningsih, I. E. (2014). Pengaruh Interaksi Sosial Keluarga, Motivasi Belajar dan Kemandirian Belajar terhadap Prestasi Belajar. Jurnal Pendidikan dan Kebudayaan, 20(4), 441-451. https://www.neliti.com/publications/1249 12/pengaruh-interaksi-sosial-keluargamotivasi-belajar-dan-kemandirian-belajarterh.

Nurfitriyanti, M., Rosa, N. M., \& Nursa'adah, F. P. (2020). Pengaruh Kemampuan Berpikir Kritis, Adversity Quotient dan Locus of
Control terhadap Prestasi Belajar Matematika. Jurnal Kajian Pendidikan Matematika, 5(2), 263-272. https://journal.lppmunindra.ac.id/index.ph $\mathrm{p} / \mathrm{jkpm} /$ article/view/5929/3142.

Pane, A. \& Dasopang, M. D. (2017). Belajar dan Pembelajaran. Fitrah Jurnal Kajian IlmuIlmu Keislaman, 3(2), 333-352. http://jurnal.iainpadangsidimpuan.ac.id/index.php/F/articl e/view/945/795.

Prasasty, A. T. (2017). Pengaruh Disiplin dan Motivasi Belajar terhadap Prestasi Belajar Matematika Siswa Kelas X SMK Bina Karya Insan Tangerang Selatan. Jurnal Ilmiah Pendidikan dan Ekonomi, 1(1), 6574.

http://journal.stkipnurulhuda.ac.id/index.p hp/utility/article/view/64/44.

Pratama, H. F. A. \& Arief, S. (2019). Pengaruh Pemanfaatan E-learning, Lingkungan Teman Sebaya, dan Motivasi Belajar terhadap Prestasi Belajar. Jurnal Pendidikan Ilmu Pengetahuan Sosial, 6(1), 1-12. http://ejournal.uinmalang.ac.id/index.php/jpips/article/view/ 7811.

Pratiwi, N. K. (2015). Pengaruh Tingkat Pendidikan, Perhatian Orang Tua dan Minat Belajar Siswa terhadap Prestasi Belajar Bahasa Indonesia Siswa SMK Kesehatan di Kota Tangerang. Jurnal Pujangga, 1(2), 75-105. http://journal.unas.ac.id/pujangga/article/v iew/320/218.

Pujiono, S. (2012). Berpikir Kritis dalam Literasi Membaca dan Menulis untuk Memperkuat Jati Diri Bangsa. Prosiding Bahasa dan Sastra Indonesia, hlm. 778-783, JPBSI FBS UNY. http://staffnew.uny.ac.id/upload/1323181 27/penelitian/Berpikir+Kritis+dalam+Pem bel+Membaca+dan+Menulis+(Prisiding+ + PIBSI).pdf.

Puspasari, D. \& Puspasari, D. (2019). Development of Student Worksheet Based on Problem Based Learning in Office Management Subject. International 
Journal of Educational Research Review, 4(3), 379-385.

http://www.ijere.com/frontend//articles/pd f/v4i3/journal-durinta-puspasari-anddurinda-puspasaripdfpdf.pdf.

Putri, M. S., Daharnis, \& Zikra. (2017). Hubungan Kontrol Diri dengan Perilaku Membolos Siswa. Konselor, 6(1), 1-5. http://ejournal.unp.ac.id/index.php/konsel or/article/view/6441/5976.

Rachmaniar, A. (2020). Pengaruh Kontrol Diri terhadap Pembuatan Keputusan Karier Siswa. Jurnal Bimbingan dan Konseling, 4(1), 7-13. http://www.journal.unindra.ac.id/index.ph p/teraputik/article/view/281.

Ramdhan, M. Y. \& Harsono, L. D. (2015). Pengaruh Motivasi Belajar terhadap Prestasi Belajar Mahasiswa Telkom University Program Pendidikan Jarak Jauh Tahun Akademik 2013/2014 (Studi Kasus pada Program Pasca Sarjana). EProceeding of Management, hlm. 156-161, Prodi Manajemen Bisnis Telekomunikasi dan Informatika Fakultas Ekonomi dan Bisnis, Universitas Telkom. https://openlibrarypublications.telkomuni versity.ac.id/index.php/management/articl e/view/1145.

Rohmatun, S., Fathoni, A., \& Haryono, A. T. (2018). Pengaruh Gaya Kepemimpinan Birokratis, Peraturan dan Kontrol Diri terhadap Burnout melalui Self Efficacy sebagai Variabel Intervening pada Mahasiswa Santri (Studi Kasus Pondok Pesantren Darussalam Semarang). Journal of Management, 4(4), 1-14. http://jurnal.unpand.ac.id/index.php/MS/a rticle/download/1114/1088.

Rosana, L. N. (2014). Pengaruh Metode Pembelajaran dan Kemampuan Berpikir Kritis terhadap Hasil Belajar Sejarah Siswa. Jurnal Pendidikan Sejarah, 3(1), 34-44.

http://journal.unj.ac.id/unj/index.php/jps/a rticle/view/991.
Rusman. (2017). Belajar dan Pembelajaran Berorientasi Standar Proses Pendidikan. Jakarta: Kencana.

Sekaringtyas, T. (2017). Pengaruh Motivasi Berprestasi dan Kemampuan Berpikir Kritis terhadap Hasil Belajar Ilmu Pengetahuan Alam Siswa SDN Sukatani IV. Jurnal Pendidikan Dasar, 8(2), 159171.

http://journal.unj.ac.id/unj/index.php/jpd/a rticle/view/5733.

Sihaloho, F. A. S. (2017). Hubungan Kemampuan Berpikir Kritis dan Soft Skills dengan Prestasi Belajar Siswa pada Mata Pelajaran Ekonomi Kelas XI SMAN Labuhan Deli T.P 2015/2016. Prosiding Seminar Pendidikan Ekonomi dan Bisnis, hlm. 1-7, Universitas Sebelas Maret. https://jurnal.fkip.uns.ac.id/index.php/snp e/article/view/10648/7894.

Sriyanti, L. (2012). Pembentukan Self Control dalam Perspektif Nilai Multikultural. MUDARRISA Jurnal Kajian Pendidikan Islam, 4(1), 68-89. https://mudarrisa.iainsalatiga.ac.id/index.p $\mathrm{hp} /$ mudarrisa/article/view/1439.

Sugiyono. (2019). Metode Penelitian Kuantitatif, Kualitatif dan R\&D. Bandung: Alfabeta.

Suherman, M. M. (2016). Efektivitas Strategi Permainan dalam Mengembangkan SelfControl Siswa. Jurnal Penelitian Pendidikan LPPM Universitas Pendidikan Indonesia, 16(2), 194-201. https://ejournal.upi.edu/index.php/JER/art icle/view/4246.

Sunadi, L. (2013). Pengaruh Motivasi Belajar dan Pemanfaatan Fasilitas Belajar terhadap Prestasi Belajar Siswa pada Mata Pelajaran Ekonomi Kelas XI IPS di SMA Muhammadiyah 2 Surabaya. Jurnal Pendidikan Ekonomi (JUPE), 1(3), 1-19. https://ejournal.unesa.ac.id/index.php/jupe /article/download/3628/6224.

Sunarsi, D. (2017). Pengaruh Disiplin, Motivasi dan Kompetensi terhadap Prestasi Belajar (Studi Kasus pada Mahasiswa Universitas Pamulang, Tangerang Selatan Tahun Akademik 2016-2017). Jurnal Mandiri 
Ilmu Pengetahuan, Seni dan Teknologi, 1(2), 208-226. http://jurnalmandiri.com/index.php/mandi ri/article/view/19

Suprihatin, S. (2015). Upaya Guru dalam Meningkatkan Motivasi Belajar Siswa. Jurnal Program Studi Pendidikan Ekonomi, 3(1), 73-82. https://ojs.fkip.ummetro.ac.id/index.php/e konomi/article/view/144.

Supriyanto, S. (2018). Motivasi Belajar dan Tingkat Intelegensi terhadap Prestasi Belajar. Herodotus, Jurnal Pendidikan IPS, 1(2), 101-118. https://journal.lppmunindra.ac.id/index.ph p/herodotus/article/view/3752.

Syafi'i, A., Marfianto, T., \& Rodiyah, S. K. (2018). Studi tentang Prestasi Belajar Siswa dalam Berbagai Aspek dan Faktor yang Mempengaruhi. Jurnal Komunikasi Pendidikan, 2(2), 115-123. http://journal.univetbantara.ac.id/index.ph p/komdik/article/view/114/102.

Triastutik, A. \& Sutoyo, A. (2020). Hubungan Kontrol Diri dengan Perilaku Disiplin Tata Tertib Sekolah pada Siswa SMA. Indonesian Journal of Guidance and Counseling, $\quad 9(1), \quad 41-45$. https://journal.unnes.ac.id/sju/index.php/j bk/article/view/35783.

Undang-Undang Republik Indonesia Nomor 20 Tahun 2003. Sistem Pendidikan Nasional. Jakarta: Lembaran Negara Republik Indonesia Tahun 2003 Nomor 4301.

Wicaksono, A. G. C. (2014). Hubungan Keterampilan Metakognitif dan Berpikir Kritis terhadap Hasil Belajar Siswa SMA pada Pembelajaran Biologi dengan Strategi Reciprocal Teaching. Jurnal Pendidikan Sains, 2(2), 85-92. https://media.neliti.com/media/publication s/123065-ID-none.pdf.

Zubaidah, S. (2010). Berpikir Kritis: Kemampuan Berpikir Kritis Tingkat Tinggi yang Dapat Dikembangkan melalui Pembelajaran Sains. Prosiding Seminar Nasional Sains, hlm. 1-14, Jurusan Biologi FMIPA Universitas Negeri Malang.
https://www.researchgate.net/profile/Siti Zubaidah5/publication/318040409_Berpi kir_Kritis_Kemampuan_Berpikir_Tingkat _Tinggi_yang_Dapat_Dikembangkan_me lalui_Pembelajaran_Sains/links/59564c65 0f7e9b591cda994b/Berpikir-Kritis-

Kemampuan-Berpikir-Tingkat-Tinggi.

Zubaidah, S. (2018). Mengenal 4C: Learning and Innovation Skills untuk Menghadapi Era Revolusi 4.0. Prosiding Seminar Science Education National Conference, hlm. 118, Jurusan Biologi FMIPA Universitas Negeri Malang. https://www.researchgate.net/profile/Siti Zubaidah5/publication/332469989_MEN GENAL_4C_LEARNING_AND_INNO VATION_SKILLS_UNTUK_MENGHA DAPI_ERA_REVOLUSI_INDUSTRI_40 _1/links/5cb73e77a6fdcc1d499bb356/ME NGENAL-4C-LEARNING-ANDINNOVATION-SKILLS-UNTUKMENGHADAPI-ERA. 